\title{
A instrumentalização do discurso do medo: pastores midiáticos e o período pré-eleitoral de 2014
}

Instrumentalising the discourse of fear: media pastors and the pre-election of 2014

La instrumentalización del discurso del miedo: pastores mediáticos durante el período preelectoral de 2014

DOI: 10.1590/1809-5844201926

\section{Leandro Ortunes ${ }^{1}$}

https://orcid.org/0000-0003-3966-8043

\section{Silvana Gobbi Martinho ${ }^{1}$}

https://orcid.org/0000-0002-7052-7460

\section{Tathiana Senne Chicarino ${ }^{1}$}

https://orcid.org/0000-0002-9306-5668

${ }^{1}$ (Pontifícia Universidade Católica de São Paulo, Faculdade de Ciências Sociais, Programa de Estudos PósGraduados em Ciências Sociais. São Paulo - SP, Brasil).

\section{Resumo}

Em tempos de pluralidade de ideias e valores morais, determinadas lideranças religiosas buscam se reafirmar como fontes da verdadeira moral e combater certos tipos de pensamento que possam desestabilizar seu modus operandi. Diante disso, os períodos pré-eleitorais, por muitas vezes, se tornam um momento propício para o engajamento religioso no debate político, com a intenção de influenciar a decisão de voto do fiel. Nesse sentido, o objetivo deste trabalho é analisar as formas de engajamento político, por parte de dois pastores midiáticos - Silas Malafaia e Marco Feliciano - na mídia tradicional e nas redes sociais digitais. Apresentaremos os seus posicionamentos diante de pautas progressistas que, a partir da redemocratização, começam a ser vinculadas à esquerda, ao Partido dos Trabalhadores, e as suas propostas políticas, fundamentadas em princípios messiânicos e salvacionistas. Nossa hipótese é que o discurso do medo é empregado por esses pastores neopentecostais como forma de manutenção de uma determinada ordem, ditada pela religião na qual se filiam.

Palavras-chave: Midiatização da religião. Cultura do medo. Neopentecostais. Eleições de 2014. Pensamento conservador. 


\begin{abstract}
In times of plurality of ideas and moral values, some religious leaders seek to reaffirm themselves as sources of true morality and to combat any kind of thinking that could destabilize their "modus operandi". In view of that, pre-election periods often become a propitious moment for religious engagement in the political debate with the intention of influencing the vote decision of the faith. In this sense, the objective of this work is to analyze the forms of political engagement, by two media pastors - Silas Malafaia and Marco Feliciano - in traditional media and social networks. We will present their positions in the face of progressive lines traditionally linked to the Left and the Workers' Party, and their political proposals based on Messianic and Salvationist principles. Our hypothesis is that the discourse of fear is employed by these Neo-Pentecostals pastors as a way of maintaining order, dictated by the religion they join.
\end{abstract}

Keywords: Mediatization of religion. Culture of fear. Neopentecostals. Elections 2014. Conservative thinking.

\title{
Resumen
}

En un momento que se vive la pluralidad de ideas y valores morales, determinados liderazgos religiosos buscan reafirmarse como fuentes de la verdadera moral y combatir ciertos tipos de pensamientos que puedan desestabilizar su modus operandi. Frente a esto, los periodos preelectorales, suelen volverse un momento propicio para la inserción religiosa en el debate político con la intención de influenciar el voto de su fiel. Teniendo esto en cuenta, el objetivo de este trabajo es analizar las formas de inserción política, por parte de los dos pastores de los mass medias, - Silas Malafaia y Marco Feliciano - en los medios de comunicación tradicionales y en las redes sociales digitales. Presentaremos sus posiciones frente a las pautas progresistas, que a partir de la redemocratización comenzaron a ser vinculadas a la izquierda, al Partido de los Trabajadores (Partido dos Trabalhadores) y sus propuestas políticas fundamentadas en principios mesiánicos y de salvación. Nuestra hipótesis es que el discurso del miedo es empleado por esos pastores neopentecostales como forma de mantener una determinada orden, dictada por la religión a la cual se afilian.

Palabras clave: Mediatización de la religión. Cultura del miedo. Neopentecostales. Elecciones 2014. Pensamiento conservador.

\section{Religião, política e o discurso do medo}

Nos últimos anos, vivenciamos um processo de forte engajamento de líderes religiosos na esfera política. Muitos autores dedicaram-se a compreender esse deslocamento da vida privada para o espaço público da religião, como, por exemplo, Habermas (2006), Burity (2001), Dantas (2011), Zabatiero (2008), Machado (2006), Cunha (2017), entre outros. Esses estudos nos fornecem uma importante reflexão sobre este fenômeno, nomeado por alguns como a desprivatização da religião (MARTINO, 2016; CASANOVA, 1994), e permitem concluir que houve um deslocamento da prática religiosa e dos valores das relações intra-eclesiais para o debate político na busca por impor tais valores aos demais 
membros da sociedade. No Brasil, esse processo de desprivatização se acentua com o surgimento do neofundamentalismo, um movimento político-religioso, já identificado por Oro (2016), que busca a defesa da fé não por um isolacionismo do fundamentalismo clássico, mas, sim, pela imposição de valores e sua atuação na política. Segundo Cunha (2017), o “neo” é aplicado devido ao aumento de visibilidade de lideranças conservadoras, que se apresentaram como representantes dos novos tempos dentro de um cenário de fortalecimento de posturas conservadoras na esfera pública brasileira, principalmente no contexto das eleições. E uma das formas de atuação deste grupo, que pretendemos apresentar aqui, é o discurso da promoção do medo como instrumento de dominação e de direcionamento das intenções de voto.

O medo sempre esteve presente nas relações sociais como fator de coesão política e de estruturação do poder, especialmente sistematizado pela filosofia política e pela história cultural. Em Maquiavel (1969), o medo aparece como o motor das ações humanas, sempre considerado para delimitar e direcionar a ação do príncipe. O autor renascentista rompe o paradigma epistemológico vigente ao tratar a política como um campo autônomo, com imperativos próprios, afirmando que o objetivo do governante é o de se manter no poder e que todas as atitudes tomadas por ele são disto resultantes.

Assim, a partir de exemplos históricos, na obra “O Príncipe”, o autor vai indicar quais são as qualidades e ações que o governante deve ter e fazer para garantir a manutenção do poder. Virtú e fortuna aparecem como conceitos chaves de sua análise, o primeiro podendo ser compreendido como sabedoria e o segundo como as circunstâncias históricas, cabendo, portanto, ao governante apropriar-se deles de forma sábia para manter-se no poder, algo que não necessariamente se apoia em fundamentos religiosos e/ou morais.

Hobbes (1979), por sua vez, concebe a natureza humana como má e sempre sujeita à guerra ou ao conflito de todos contra todos. Desse conflito potencial é que surge um dos medos mais instrumentalizados politicamente: o medo da morte. Este é o elemento principal do contrato social, que levará a formação de um Estado soberano, que, em troca da garantia da vida de seus súditos, tomará deles a opção pela liberdade. Contudo, e apesar do contrato, o medo não cessa, apenas passa a ser controlado por esse Estado, incidindo em uma estrutura mental que, pela esperança de uma vida melhor, suporta a manutenção de governos autoritários. Nessa dinâmica, a religião tem um grande potencial de contingenciamento (HOBBES, 1979). De fato, compreendemos que: “O medo torna o governante, a pretexto de proteger seus súditos de ameaças externas ou internas, absoluto em seu poder” (KEHL, 2007, p. 95).

No que tange ao âmbito religioso, os medos se diversificam, embora sejam intrinsecamente ligados à oposição sagrado e profano, pois são interpretações de uma realidade articulada a fantasias e inseguranças: "Quero lembrar que medo é uma das fontes de fantasia e da invenção, e que grande parte dele provém das mesmas fontes do mistério e do sagrado” (KEHL, 2007, p. 91). Nesse sentido, o processo de demonização do “outro” passa a ser uma das formas de atuação do fundamentalismo, pois se contrapõe ao intenso processo 
de secularização e da retração do nível de importância do sagrado na vida da sociedade (ORO, 1996), no que Weber (1991) nomeia de desencantamento do mundo.

Portanto, assim como o medo pode ser fabricado e produzido por um sistema político para estimular a obediência dos cidadãos em determinadas sociedades (CHAIA, 2014), ele também pode ser produzido pela religião com esses mesmos objetivos, pois as religiões, muitas vezes, alimentam-se da confusão entre a causa real de um evento e seu antecedente na experiência, cabendo à própria religião buscar interpretações sobre o fenômeno em questão (LIMONGI, 2007). E, em sociedades em que a oralidade sucumbe cada vez mais à intermediação do relato, da experiência pela narrativa da imprensa e das redes sociais digitais, não é de se estranhar que essa produção de medos tenha a Igreja como uma instituição de grande difusão, como nos diz Glassner (2003), se concentrando especialmente em fatos que não são em si temidos, mas que são amplificados por determinadas lideranças.

Nesse sentido, buscaremos, no decorrer do texto, compreender a forma como Silas Malafaia e Marco Feliciano, dois pastores midiáticos, instrumentalizam os meios de comunicação, especialmente as redes sociais digitais, para difundir um discurso calcado no medo e em elementos simbólicos advindos do messianismo e do salvacionismo.

Nossos procedimentos de pesquisa seguem as proposições trazidas por Yin (2009) no que se refere à análise de um estudo de caso crítico, quando este pode representar uma contribuição relevante para a formação do conhecimento e da teoria em futuras investigações do campo de pesquisa em questão, sendo base para explanações e generalizações significativas (YIN, 2009). Assim, adotamos a triangulação metodológica, que pode combinar técnicas qualitativas e quantitativas, como suporte à coleta e análise dos dados, que advêm de: 1 . dados estatísticos descritivos; 2. análise documental; 3. análise de discurso.

Isso porque nossa premissa é que o discurso político messiânico e salvacionista se desenvolve em um ecossistema informativo onde se articulam conteúdos da imprensa tradicional, conteúdos das redes sociais digitais e conteúdos dialógicos presentes no cotidiano, como, por exemplo, em pregações e cultos religiosos, podendo ser confirmado pelo estudo de caso de Malafaia e Feliciano.

Neste sentido, Cunha (2017) apresenta um estudo detalhado que fundamenta a necessidade de também compreender a atuação de líderes religiosos nas redes sociais digitais, principalmente a sua grande capacidade de alcance. Esses líderes, percebendo que a Internet é um espaço apropriado para combater as mídias tradicionais e seus produtos midiáticos, buscam agora, por meio delas, disseminar suas ideias. Cunha (2017) parte da ideia de que podemos observar, no atual contexto do reacionarismo movido pelo neoconservadorismo evangélico, o desenvolvimento de novos processos comunicacionais midiáticos como armas na "guerra contra os inimigos da família”, sendo as mídias sociais um ambiente fértil para isso.

Com o surgimento do movimento neofundamentalista por volta dos anos 1990, a relação entre religião e política se alterou no Brasil (ORO, 1996). Evangélicos, tradicionais e fundamentalistas, que eram apáticos à participação política, passaram a buscar formas 
de consolidar projetos de hegemonia calcados na defesa dos valores de sua religião e em oposição ao pluralismo de ideias típico do pensamento progressista, que cria uma condição de incerteza em relação ao seu modo de crer e de viver (BERGER, 1994).

Com esse intuito, determinados líderes religiosos passaram a atuar na esfera política munidos de uma pauta conservadora ${ }^{1}$ que, a um passo, é um contraponto à pluralidade e diversidade identificadas no campo progressista, e que, a outro, se instrumentaliza na defesa de uma dada ordem pelo temor constante.

Diante desse contexto, nossa premissa é a de que esse ativismo conservador se estendeu a um momento ímpar da democracia - os precedentes da formação da opinião pública que se materializa no voto - no caso em que analisamos, o período anterior às eleições de 2014, marcado por uma intensa polarização nas ruas e nas redes.

Assim, uma das principais estratégias foi a busca pelo agendamento ${ }^{2}$ da mídia tradicional, ou o contra-agendamento, pelo engajamento nas redes sociais, fato que nos remete ao pensamento de Bourdieu (1997, p. 28):

Um dos móveis das lutas políticas, a nível das trocas cotidianas ou na escala global, é a capacidade de impor princípios de visão de mundo, óculos tais que as pessoas vejam o mundo segundo certas visões (os jovens, os velhos, os estrangeiros e os franceses). Ao impor essas divisões, formam-se grupos, que se mobilizam e que, ao fazer isso, podem chegar a convencer de que existem, a fazer pressão e a obter vantagens.

O discurso político-midiático disseminado pelos pastores em questão e incorporado ao léxico tanto de seus fiéis, quanto de opositores do PT, apresentam visões de mundo extremadas em sua dualidade e retomam alguns termos típicos dos anos da Guerra Fria e que já produziram medo na população, como comunismo e ditadura. Sendo que objetivam, ao viralizar nas redes sociais digitais certos conteúdos (ver figuras abaixo), criar um estado de perigo iminente caso o governo do Partido dos Trabalhadores (PT) permanecesse no poder.

O fluxo de conteúdos não se limita às diferentes plataformas midiáticas (JENKINS, 2008), mas vão para as ruas, se transformando até mesmo em adesivos para automóveis, como exemplo, o banner "fora Collor" adaptado para "fora Dilma”. Além disso, se coloca em um certo tipo de fluxo temporal em que há o acionamento de memórias políticas, ou seja, ao remeter a imagem de “fora Dilma” a "fora Collor”, buscou-se vincular o período de 2014

\footnotetext{
1 Foram muitas as tentativas de influenciar a agenda pública. Citamos, como exemplo, o caso do material contra homofobia que seria distribuído pelo MEC durante a gestão de Fernando Haddad como ministro e que foi nomeado por evangélicos como kit gay. Além do debate sobre sexualidade em escolas, que foi duramente criticado por eles como ideologia de gênero já durante as eleições de 2014. Recentemente, em 2018, esses temas voltaram à agenda, reforçando um discurso de ódio que pôde substanciar o medo. Cabe destacar que o então presidenciável Jair Bolsonaro, em entrevista ao Jornal Nacional, apresentou o tal kit gay. Disponível em: https://www. youtube.com/watch?v=uVGQ2vzJW7E. Acesso em: 7 maio 2019.

2 De acordo com Azevedo (2004), a agenda da mídia é a capacidade que esta tem de dar visibilidade e proeminência a determinados temas em detrimento de outros num período delimitado, assim, os meios de comunicação de massa nos submetem a processo de hierarquização desses temas e pessoas.
} 
ao período Collor, marcado pela inflação e pela corrupção empreendidas pelo presidente em questão. Temos, assim, a junção entre a cultura do medo dialeticamente operados em símbolos e discursos que são politicamente consequência do que a sociedade se recorda de suas experiências passadas (SOUZA; LAMOUNIER, 1990).

Figura 1 - Comparativo entre capa do livro "Fora Collor” e o adesivo "fora Dilma”

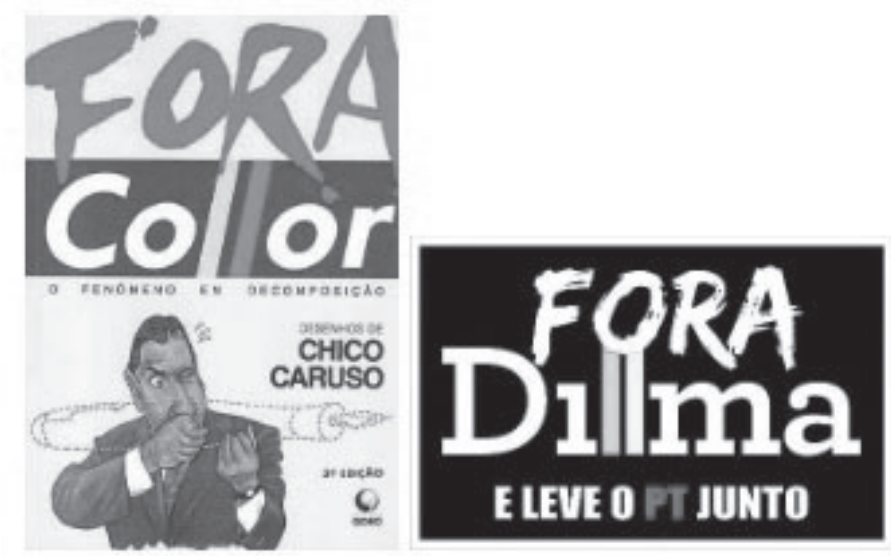

Fonte: Livro “Fora Collor o fenômeno em decomposição” (1993) e adesivo “fora Dilma” (2014). Destaca-se que os LL em verde e amarelo são utilizados de forma adequada quando referenciados ao nome do presidente Collor. O recurso visual foi forçado para Dilma, uma vez que seu nome é escrito apenas com um L em sua grafia.

O recurso do medo não é algo novo nas campanhas políticas religiosas. Pierucci e Mariano (1992) descrevem que, em 1989, os evangélicos aderiram à campanha de Collor por recearem à vitória de Lula. O primeiro cenário possível seria a implantação do comunismo que, por sua vez, segundo eles, limitaria as liberdades religiosas, e o segundo seria a retomada da hegemonia da Igreja Católica, principalmente devido à ligação do PT com a Teologia da Libertação e das Comunidades Eclesiais de Base. Do mesmo modo, em 1994, lideranças evangélicas afirmaram publicamente que se Lula ganhasse, ele fecharia as igrejas evangélicas, uma suposta atitude do então presidente que é reinterpretada por Marco Feliciano na nova conjuntura política, já que o pastor, nesse momento, buscava apoio à candidatura de Dilma Rousseff em um movimento de aproximação entre PT e certos líderes evangélicos que remonta às eleições de 2012.

Importante destacar que, embora passassem a apoiar Lula, houve a manutenção dos princípios salvacionistas característicos de seus discursos. Assim, em uma reunião com pastores, reelabora uma imagem anteriormente propagada por eles próprios e que se altera substancialmente a partir de 2014:

A história de Luiz Inácio Lula da Silva, nestes últimos 8 anos, tocou o mundo todo. A figura dele não é mais visto só como presidente, mas como uma figura messiânica, não comparado a Cristo, mas como alguém que desperta esperança 
no povo. [...] Eu fui um dos que fui pregador na época e esparramei pelos cultos do Brasil, porque eu ouvia e como papagaio eu repetia, “o PT vai fechar as igrejas do Brasil!”. [...] Oito anos atrás o Lula era o demônio, mas Lula foi eleito, nenhuma igreja foi fechada e o país cresceu [sic.] ${ }^{3}$.

\section{O discurso político-religioso}

Buscando analisar as formas de discurso do medo na campanha eleitoral de 2014, escolhemos dois personagens que fazem parte do movimento neofundamentalista. Nosso critério de escolha se orientou por uma pesquisa realizada na Marcha para Jesus ${ }^{4}$, do ano de 2016, em que, segundo resultados obtidos, Silas Malafaia foi identificado pelos evangélicos entrevistados como sendo o personagem midiático que mais os representava, enquanto Marco Feliciano se destacou como a figura política mais representativa. Nos gráficos abaixo podemos observar os níveis de representatividade destes e de outros personagens.

Gráfico 1 - Representatividade de personagens na mídia

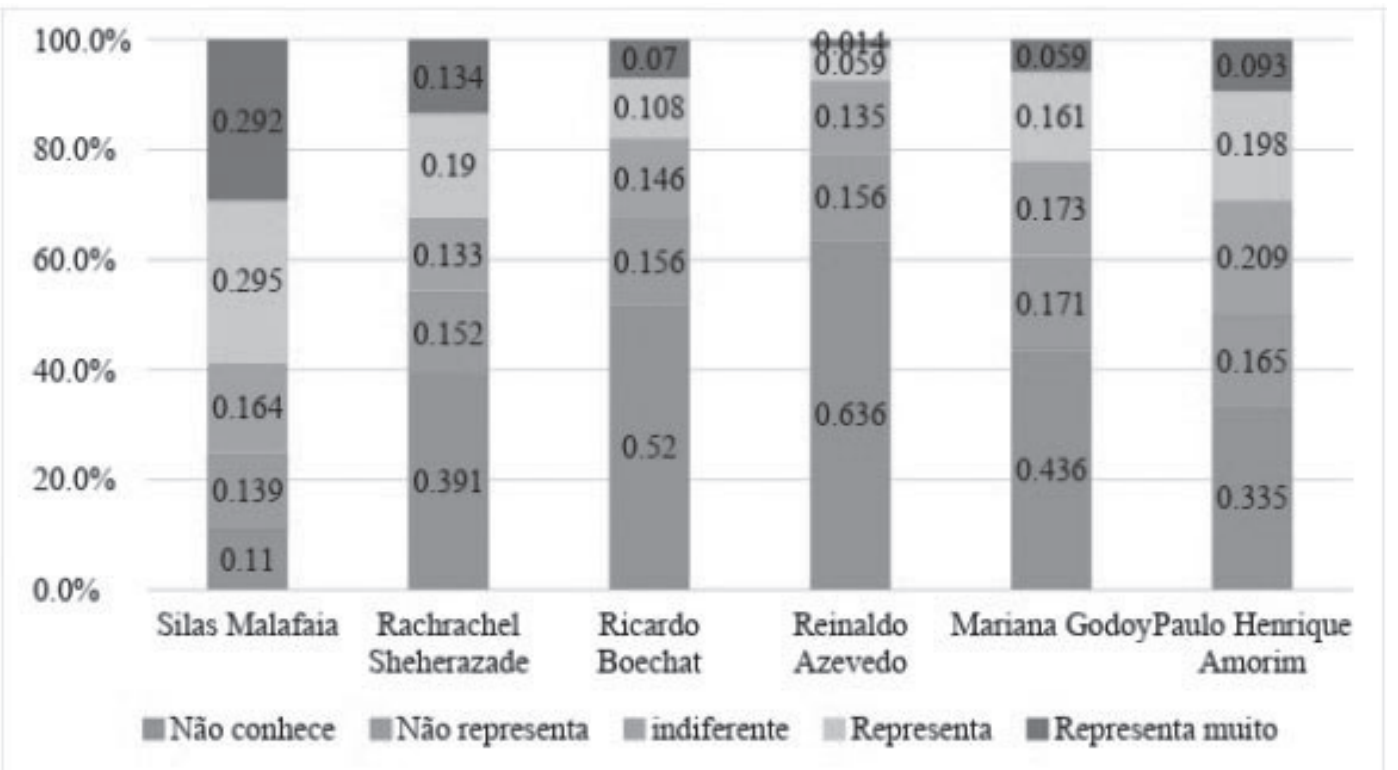

Fonte: MIRE, Pesquisa Marcha Para Jesus 2016.

3 Disponível em: https://www.youtube.com/watch?v=Go6rD4xGli8. Acesso em: 5 jun. 2017.

4 A Marcha para Jesus é um evento internacional realizado por igrejas evangélicas e liderado pela Igreja Renascer em Cristo que reuniu, em sua $25^{\circ}$ edição de 2017, milhões de pessoas na região da Luz na capital paulista. 
Gráfico 2 - Representatividade de personagens políticos

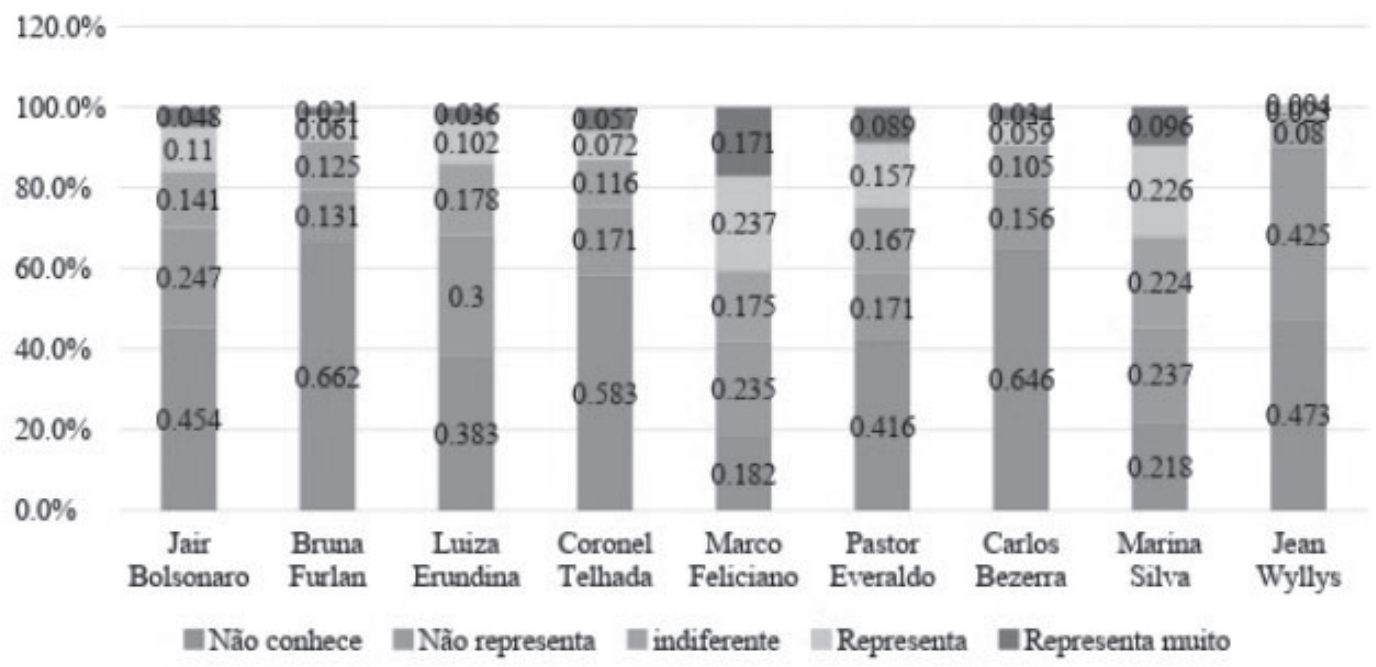

Fonte: MIRE, Pesquisa Marcha Para Jesus 2016.

Somando as categorias representa e representa muito, temos os seguintes resultados: Silas Malafaia (58,7\%) e Marco Feliciano (41,8\%). Além disso, devemos considerar que ambos são pastores midiáticos e pertencentes à igreja Assembleia de Deus, sendo que, de acordo com o IBGE (2010), 5,7\% da população brasileira declarou pertencer a esta denominação, fato que a torna o maior segmento religioso do país, excluindo o catolicismo. Diante desses aspectos, fica evidente a importância de analisarmos este público e estes líderes religiosos.

Primeiramente, antes de apresentarmos alguns discursos religiosos, é necessário destacar quem são esses personagens e os elementos simbólicos que carregam em suas falas. Ambos são pastores famosos, se destacam pelo carisma, pela impostação de voz e pela boa articulação na mídia. Tendo presença cativa em programas e talk shows da TV aberta, já tiveram inúmeras oportunidades de abordar temas como homossexualidade, aborto e drogas, ou seja, todos referentes à pauta conservadora do neofundamentalismo. Sobre a questão teológica, usam praticamente os mesmos recursos para convencer seu público e direcionar o debate. Um dos elementos simbólicos utilizado por eles foi analisado por Preuss (2015) como o profetismo, ou o termo profeta, que, segundo a teologia hebraico-cristã, é o responsável pelo recado divino, geralmente transmitindo uma mensagem crítica, negativa para as classes dominantes e com uma carga de esperança para o povo oprimido. Com isso, o profeta assume uma figura de porta-voz de Deus em defesa do povo.

A alusão à figura do profeta é recorrente nas pregações de Malafaia. Em diversos sermões ele se autointitula "profeta de Deus". Esse fato nos chamou atenção desde o começo de nossa pesquisa, pois visualizamos uma relação entre 
a utilização do termo e a posição que o apresentador assume para legitimar sua postura política na ocupação do telespaço público (PREUSS, 2015, p. 108).

Preuss (2015) ainda comenta que Silas Malafaia utiliza o estereótipo que retrata o evangélico como inocente ou ingênuo como um dos pilares de sustentação de seu discurso, para se colocar no papel de auxiliador para iluminação dos fiéis, para instruí-los, para alertá-los, sendo estes atributos do personagem profeta. Nesse sentido, Silas Malafaia é um dos "profetas” que anuncia que é chegado esse "reino dos céus”, ou seja, a hora de mudança na sociedade. Conforme a pesquisa da autora, Silas Malafaia parece querer alcançar, além de novos fiéis, votos para os representantes evangélicos e mais visibilidade no telespaço público.

Marco Feliciano também se utiliza dos mesmos recursos citados no estudo de Preuss (2015) em relação à Malafaia. O profetismo é marcante em várias de suas pregações e um fato que nos chamou atenção foi o uso do termo durante sua campanha para deputado em 2014. Feliciano, ao solicitar ajuda para divulgação de sua candidatura, ao invés de citar "santinhos”, como são chamados os panfletos políticos, os chamou de "profetinhas", obviamente vinculando o termo à sua imagem:

Você que mora no Estado de São Paulo e gostaria de me ajudar e ser meu voluntário [...] voluntário por que, pastor? Porque eu não tenho nenhum centavo de dinheiro para pagar você, pra você me ajudar a distribuir meus panfletos, mas você que é voluntário, que acredita na família, que acredita na minha luta [...] eu preciso que você entre agora na Internet [...] você pode enviar um e-mail com seu endereço e eu vou mandar pra você um kit de material, neste kit vai ter os profetinhas [...] eu não uso santinho, aqueles papeizinhos de políticos são chamados de santinhos, santo para mim só Deus é, então, eu vou mandar pra você alguns profetinhas [sic.] ${ }^{5}$.

Ainda sobre a questão do profetismo, é importante ressaltar que, para a teologia, as palavras do profeta são carregadas de um poder mágico que deve promover certa obediência em seus seguidores. Weber (2010) comenta que, na realidade, a obediência é determinada por motivos muito fortes entre o medo e a esperança, sendo que o medo pode ser da vingança dos poderes mágicos do detentor do poder, ou seja, medo do castigo da divindade ou do profeta. Por outro lado, há esperança de recompensa nesse mundo ou no outro quando o fiel segue os conselhos do profeta. Preuss (2015) destaca algumas frases de Malafaia, que podemos considerar como uma nítida tentativa de profecia:

Ele utiliza expressões como: “ninguém vai cercear a nossa cidadania”, “eu sei do que eu tô falando”, “eu não tenho medo” e chega ao ponto de dizer: "Eu tô

5 Disponível em https://www.youtube.com/watch?v=L6pMi7UrqJ8. Acesso em: 8 jun. 2017. 
declarando aqui, vai cair, quem se levantar contra a igreja de Jesus vai cair. Vai cair, vai cair em nome de Jesus” (PREUSS, 2015, p. 114).

Preuss (2015) destaca a utilização de outros termos mobilizados por Malafaia, entre eles está: “esquerdopatas”, “os facínoras”, os que empreendem uma "perseguição pior que a nazista”, “o ativismo gay”, os crentes “otários que fazem o jogo dos ímpios”, os pastores “corruptos” que aceitam suborno dos políticos "bandidos”, os políticos “corruptos”, "safados”, "ladrões”, os profissionais da política “malandros” e os “ímpios”. Da mesma forma, Maranhão (2015) e Nascimento (2013) destacam como essas palavras são utilizadas de forma violenta, em particular, quando Malafaia diz "eu amo homossexuais como eu amo bandidos”, conectando homossexualidade à criminalidade e à abominação. Esse jogo de palavras, deslocados de sua realidade, promove um pior entendimento sobre tais assuntos e uma intolerância sistemática entre seus seguidores.

Como descrevemos anteriormente, movimentos religiosos e conservadores neofundamentalistas uniram seus discursos contra os candidatos do PT, principalmente contra a presidenta Dilma Rousseff nos antecedentes das eleições de 2014. A partir dessa reorientação, os atores políticos selecionados em nossa pesquisa, Silas Malafaia e Marcos Feliciano, alinharam suas estratégias discursivas na tentativa de reduzir a quantidade de votos do PT por parte do público evangélico. A tônica dos discursos é trabalhada como um alerta, mais uma vez, retomando a essência do profetismo.

\section{Silas Malafaia e Marco Feliciano contra Dilma}

O primeiro discurso que apresentaremos foi divulgado no canal do deputado Marco Feliciano (PSC), que alertava cristãos sobre o perigo das políticas públicas do PT:

Olá, pessoal! Eu sou o Marco Feliciano, deputado federal pelo estado de São Paulo e candidato à reeleição agora, em 2014, como deputado federal pelo Estado de São Paulo também [...]. Eu estou aqui hoje para fazer uma denúncia. A denúncia é sobre o que o governo tem feito para aproximar evangélicos da presidenta Dilma. Saiu há poucos dias atrás na imprensa que o PT criou um comitê evangélico pra aproximar as grandes lideranças evangélicas da presidenta Dilma. Eu queria, aqui dizer, pra você não ser enganado de novo, fizeram a mesma coisa em 2010, eu Marco Feliciano fui um daqueles [...] que acabou caindo no conto do vigário, no caso, no conto da presidenta e do PT. Eu emprestei minha imagem pra eles em 2010. Subi em palanques pedindo votos pra presidenta Dilma, porque naquele momento ela havia assinado um documento dizendo que o aborto não seria aprovado durante o mandato dela. Ela mentiu, o aborto foi aprovado através do projeto da profilaxia na gravidez.

6 "Eu amo homossexuais como eu amo bandidos: o pensamento religioso de Silas Malafaia" (NASCIMENTO, 2013). 
E há poucos dias atrás o Ministério da Saúde baixou a portaria 415 onde o aborto seria remunerado, ou seja, todos os hospitais receberiam quatrocentos reais pra que o aborto fosse efetuado. Graças à bancada evangélica, uma ação coletiva feita dentro da câmara dos deputados, conseguimos fazer com o que o ministério da saúde voltasse atrás. Todavia, o projeto chamado Cavalo de Troia, que é o projeto de profilaxia na gravidez, foi sancionado pela presidenta e já está em vigor. Os evangélicos que estão dando apoio à presidenta Dilma é a mesma turma que liderou contra mim quando eu assumi a comissão de Direitos Humanos. São evangélicos chamados evangélicos progressistas. Eles têm uma liderança aí que só Jesus na causa. Eu conheço esse pessoal, eles não comungam do nosso pensamento. Eles acham que pessoas que primam pela família, pessoas que são contra a liberação das $\underline{\text { drogas, }}$ pessoas que são contra o aborto, eles os chamam de retrocesso. Não são o governo, não pessoas do governo, que os chamam de retrocesso, são esses evangélicos esquerdistas [...] Eu apelo não só para aos evangélicos, mas a todos cristãos de bem e até as pessoas que mesmo não sendo cristãs são pessoas de família, precisamos mudar e a mudança é não votar na presidenta Dilma, não votar no PT. Muito obrigado a todos, que Deus abençoe vocês em nome de Jesus [sic.] (Grifo nosso) ${ }^{7}$.

Percebemos uma forte ênfase em temas que são sensíveis à religião - questões sobre aborto e uso de drogas - e referências aos movimentos de esquerda como parte do cenário mais tenebroso para a religião evangélica. Isso, principalmente, pelo fato de a interpretação desses elementos ser baseada exclusivamente em dogmas religiosos ou o que Croatto (2010) chamou de realidade máxima, que é a axiomatização de quaisquer comportamentos e contextos históricos dentro de sua própria verdade eterna, operando uma oposição entre o que é santo e o que é profano.

Nosso segundo exemplo trata-se da transcrição de um discurso do pastor Silas Malafaia, inicialmente divulgado em seu canal no YouTube. Malafaia se utiliza do discurso de Dilma Rousseff na ONU para alertar seu público sobre outro tipo de perigo: o terrorismo.

Olá, minha gente! Primeiro quero dizer que esse vídeo tem cenas chocantes. Peço que não permitam crianças assistirem, porque são cenas muito fortes. E quero, eu quero, aqui, fazer algumas considerações que podem decidir a nossa eleição para presidente do Brasil. Preste atenção no que eu vou falar. Em 2012, a presidente Dilma esteve na abertura da ONU [...] e na ocasião ela dá uma palavra dizendo que no mundo há uma islamofobia. Preste atenção na palavra da Dilma [sic. ${ }^{8}$.

7 Disponível em https://www.youtube.com/watch?v=ys2Ncnp858M. Acesso em: 10 nov. 2016.

8 Disponível em https://www.youtube.com/results?search_query=Malafaia+Estado+Islamico. Acesso em: 10 nov. 2016. 
Após ao aviso, é inserido um trecho da fala de Dilma, que criticava as intervenções militares ocidentais e a islamofobia que se acentuou após os atentados de 11 de setembro de 2001 nos Estados Unidos. Seguindo o depoimento da presidenta, Malafaia retoma a cena com os seguintes argumentos:

Eu mostrei pra vocês. Em 2012, a Dilma fala e defende o pessoal da fé islâmica. Em 2014, não tem uma palavra pra falar da cristofobia, que é real e verdadeira no mundo [...] lamento a omissão da fala da presidente Dilma, com os assassinatos em massa de cristãos em 2013, que morreram 115 mil e agora um grupo terrorista facínora que tá cometendo massacres, a presidente diz que tem que haver diálogo. Prepare aí seu estômago, não deixa criança assistir isso não. Vocês vão ver os terroristas assassinos de cristãos, tá... matando mulheres, adolescentes, homens, crianças, crucificando aldeias. Vocês vão ver a maldade deles contra cristãos. Essas cenas que vocês vão ver agora é assassinato de cristão. Preste atenção, preste bastante atenção. Veja isso aí, é essa gente que a presidente quer diálogo [sic.].

Após isso, são transmitidas cenas violentas de assassinatos, supostamente cometidos pelo grupo terrorista Estado Islâmico. No entanto, não há nenhuma fonte que garanta a legitimidade das imagens e a autoria das mortes. De qualquer forma, diante de imagens tão cruéis e chocantes, pouco resta de interpretação ao fiel espectador, uma vez que, a fala de um pastor, por muitas vezes, não necessita de grandes argumentos concretos ou científicos.

Malafaia, em uma frase no Twitter, também retoma a questão do "ativismo gay", como é chamado o movimento LGBT pelos neofundamentalistas.

Figura 2 - Twitter Silas Malafaia Oficial

$$
\text { R Silas Malafaia }
$$


Nesse sentido, conforme comenta Maranhão (2015), as falas do pastor colocam o movimento LGBT em uma posição discriminatória, assim como o eleitorado do PT. Por esse motivo, o jogo de imagens de terror, aliado à retórica do pastor e a sua atuação nas redes sociais, formam um verdadeiro espetáculo, que pode promover o medo e o ódio com objetivos políticos, que, neste caso, seria o de reduzir os votos no PT.

\section{Silas Malafaia a favor de Pastor Everaldo e de Aécio Neves - ambos adversários de Dilma}

Em 2014, Silas Malafaia declarou publicamente seu apoio ao candidato à Presidência da República pastor evangélico Everaldo Dias ${ }^{9}$, presidente do Partido Social Cristão (PSC). Uma vez que o candidato não tinha grandes intenções de voto, o pastor destaca a necessidade de ao menos "marcar presença" por meio de uma quantidade expressiva de votos de evangélicos direcionados ao pastor Everaldo.

Eu quero dizer para vocês aqui, eu acho que o ser humano é um ser inteligente independe da sua religiosidade. Deus fez o homem como um ser inteligente. Eu quero que você analise o que eu vou falar aqui, porque é que eu vou votar para presidente no pastor Everaldo, o número 20. Eu vou dar aqui algumas explicações [...] agora eu quero que você entenda, porque muita gente não entende. No primeiro turno das eleições, você vota para marcar uma posição. O segundo turno ele é só plebiscitário, isso é, ou você vota em um ou vota em outro, não tem saída. Então, é muito importante, nós, certo! Seja evangélico, seja católico, pessoas de bem, marcarmos uma posição. Existe centenas de projetos no congresso federal pra detonar a família, detonar os bons costumes da sociedade. Nós temos que marcar uma posição firme, ok! Para que Everaldo, se ele não for para o segundo turno, ele possa ter uma quantidade de votos grandes, onde nós vamos decidir o segundo turno. E aí, nós vamos sentar, chamar pra mesa pra dizer: Aqui, queridão, quer nosso apoio? Você vai assinar um documento aqui, que você não vota nisso, você vai ter que ser a favor disso. Esse é jogo político, gente! Não vai descer anjo do céu pra fazer isso não, minha gente. Então, você que é evangélico, eu conheço o Everaldo há mais de 30 anos [...] Eu tô dando aqui uma palavra, respeito sua opinião contrária, você é cidadão, é livre para votar em quem você quer, mas eu quero que você pense no que tô falando e analise. E vamo lá, vamos colocar 20 para presidente da república [sic.]. ${ }^{10}$.

9 O candidato ficou em $5^{\circ}$ lugar na disputa eleitoral de 2014, com $0,75 \%$ dos votos.

10 Disponível em: http://ultimosegundo.ig.com.br/politica/2014-07-24/malafaia-divulga-video-de-apoio-ao-pastor-everaldo.html. Acesso em: 9 jul. 2017. 
Novamente, o discurso toca na questão sobre o conceito de família. A frase "existe centenas de projetos no congresso federal para detonar a família, detonar os bons costumes da sociedade” possui dois elementos característicos no discurso do pastor, o exagero nos números ${ }^{11}$ (“centenas de projetos”) e o apelo que gera medo "pra detonar a família”.

Durante o segundo turno da eleição presidencial de 2014, Silas Malafaia declarou seu apoio a Aécio Neves nas redes sociais. Importante informar que, durante nossa pesquisa, em junho de 2017, não era mais possível encontrar os vídeos de apoio ao candidato no canal oficial do pastor. Lembramos também que, neste período, surgiram as delações contra o candidato. Portanto, no canal oficial Pastor Silas Malafaia, há apenas justificativas sobre a relação do pastor com Aécio. Entretanto, em outros canais, foi possível recuperar alguns discursos do pastor que foram vinculados em seu programa Vitória em Cristo em seu canal do YouTube.

Em um de seus discursos, Silas Malafaia elenca cinco motivos para que seu espectador vote em Aécio: “Como dizem os brasileiros, em um ditado popular: está chegando a hora da onça beber água. Eu vou dar pra você cinco motivos porque você deve votar em Aécio e não em Dilma”12. São eles:

1. Alternância de poder;

2. A não condenação dos envolvidos no mensalão nem sua expulsão do partido (PT);

3. Corrupção na Petrobrás, aprofundada pelo PT;

4. Discurso de Dilma na ONU contra as intervenções militares no Oriente Médio;

5. O PT ter sido contra o plano real em 1994.

O quarto motivo apresentado pelo pastor, o Discurso na ONU, já analisado, surge novamente sob a mesma argumentação: vinculando a imagem de Dilma ao Estado Islâmico.

Por fim, o pastor encerra com seu discurso: “Chega de PT, pra presidente Aécio 45, Deus abençoe o Brasil”"13.

Em uma entrevista concedida para o Jornal O Globo, Silas Malafaia cita a produção desse mesmo vídeo destacando que "é Aécio desde criancinha":

Sou Aécio desde criancinha. Gravei um vídeo com cinco motivos para não votar na Dilma. Motivo um: a alternância de poder, importante para o estado democrático. O Lula meteu o pau nos programas sociais do Fernando Henrique Cardoso. Eles (o PT) não conhecem uma coisa: quem deu estabilidade econômica para esse país foi o PSDB ${ }^{14}$.

11 Em outro discurso ao público, Silas Malafaia comenta que seu programa é dublado em inglês e transmitido para mais de 200 nações, sendo que, oficialmente, no mundo, temos 194 países soberanos e em boa parte deles não se fala a língua inglesa. Os exageros do pastor são uma forma de assustar seu público ou legitimar sua fala. Vídeo disponível em: https://www.youtube.com/ watch?v=KxiQJFW1GmQ. Acesso em: 10 jun. 2017.

12 Disponível em: https://www.youtube.com/watch?v=BCgzwFCF1lA. Acesso em: 11 jun. 2017.

13 Idem.

14 Disponível em: https://oglobo.globo.com/brasil/pastor-silas-malafaia-diz-estar-com-tucano-desde-criancinha-14177439. Acesso em: 11 jun. 2017. 
Silas Malafaia também declarou seu apoio a Aécio em diversos tweets, no dia 16 de outubro de 2014, durante o debate eleitoral promovido pelo SBT. Bem sintonizado nas redes sociais, o pastor lança a hashtags \#dilmavaiperderaecio45vencer, que chegou a ser a terceira mais utilizada no momento do debate.

Figura 3 - Trending topics em 16 de outubro de 2014, às 19 h45

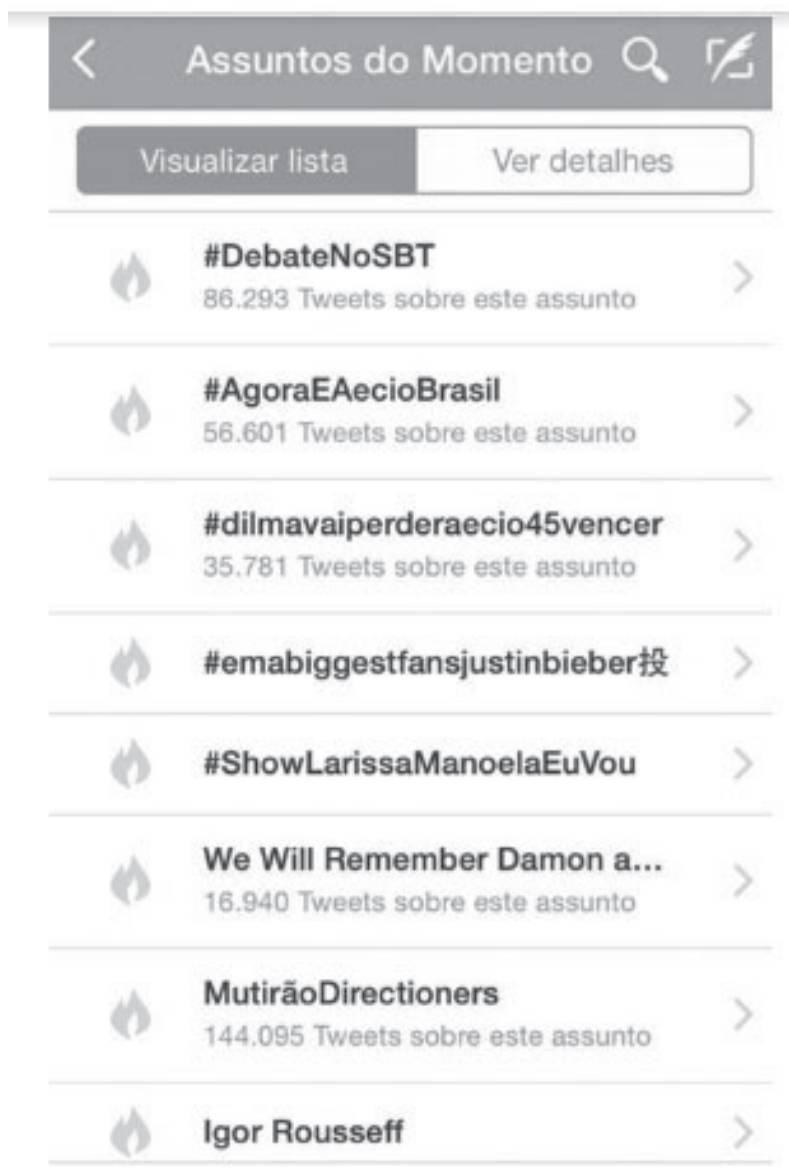

Fonte: Busca avançada do Twitter. Acesso em: 8 jun. 2017.

Em um de seus tweets ironiza Dilma, vinculando um texto bíblico, "O Diabo é o pai da mentira”, à figura da presidenta, associando-a à mãe. A sugestão do casamento entre Dilma e o Diabo faz parte do processo de demonização do outro, empenhado pelo neofundamentalismo. Além disso, há uma desqualificação de Dilma diante de afirmações sexistas: 
Figura 4 - Twitter Silas Malafaia Oficial

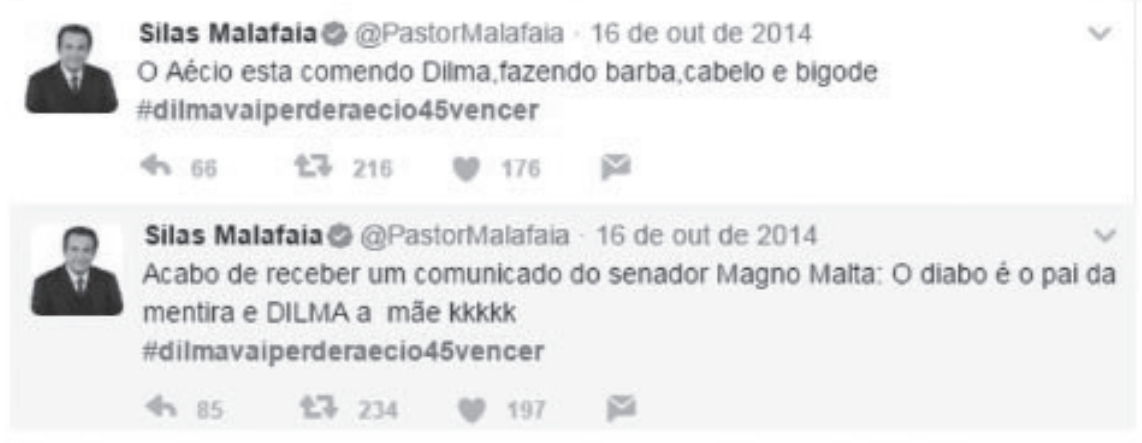

Fonte: https://twitter.com/PastorMalafaia. Acesso em: 8 jun. 2017.

Por meio do aplicativo hashtagify, conseguimos rastrear a relação da hashtag utilizada pelo pastor com as demais hashtags utilizadas em conjunto por outros seguidores, dentre elas destacamos: \#Aecio45; \#ForaDilma; \#ForaPT; \#DebatenoSBT, dentre outras.

Cabe destacar que as hashtags possuem um importante recurso discursivo, o de trazer os fatos que emergem na esfera pública a partir da lógica de storytelling, ou seja de uma narrativa noticiosa com um sentido previamente estabelecido e potencialmente de caráter compartilhado já que outros agentes não apenas podem participar desse grande mural conversacional (MALINI; ANTOUN, 2013), como são estimulados a isso.

\section{A relação de Silas Malafaia e Eduardo Cunha}

Eduardo Cunha, membro da Igreja Assembleia de Deus, foi eleito por quatro mandatos como Deputado Federal pelo Rio de Janeiro (PMDB). Em seu partido, fazia parte da chamada bancada crítica. Em 2015, foi eleito Presidente da Câmara dos Deputados, onde atuou como uma peça fundamental no processo de impeachment da ex-presidente Dilma Rousseff. Atualmente, Cunha encontra-se preso devido a participação em um esquema de corrupção da Petrobrás.

Cunha frequentou as igrejas Sara Nossa Terra e Assembleia de Deus, e seu discurso eleitoral no meio evangélico aborda os mesmos temas do movimento neofundamentalista. Em uma apresentação na igreja Assembleia de Deus Santa Cruz Areia Branca, em 11 de agosto de 2014, afirma que: "existem mais de 800 projetos de lei que atentam contra a vida, contra a família, tentam legalizar as drogas, união civil do mesmo sexo ${ }^{15}$ ”. Seu discurso se encerra com a frase "nosso povo merece respeito".

15 Disponível em: https://www.youtube.com/watch?v=-nxDRe9L6a8. Acesso em: 11 jun. 2017. 
Por mais que seu apoio ao deputado Eduardo Cunha seja negado pelo pastor Silas, encontramos vários vídeos disponíveis no YouTube de aproximações entre Malafaia e Cunha. Os vídeos não estão disponíveis no canal oficial do pastor, mas estão disponíveis em outras contas, sendo que o vídeo da Marcha para Jesus, de 2013, citado nesse texto, está disponível no canal oficial do deputado Eduardo Cunha ${ }^{16}$.

Como realmente não há apoio explícito por parte do pastor, apresentaremos as articulações no discurso político de Malafaia que deixa implícito sua aproximação a Cunha desde o ano de 2013 até o ano de 2017, ano da prisão do deputado. Para nosso estudo sobre o período pré-eleitoral, descrever essa trajetória é importante para demonstrar que, no ambiente religioso evangélico, as campanhas de engajamento político não se restringem aos momentos que antecedem a votação, assim, tomando como referência o conceito de campanha permanente como “[...] uma disputa para criar framing effect - isto é, mudanças na apresentação do problema com o intuito de alterar a percepção da opinião pública” (SAMPAIO, 2016, p. 11). Podemos compreender esse engajamento contínuo como parte de uma lógica de negociação de apoios públicos que, orientados para uma parcela significativa do eleitorado, nesse caso o eleitor evangélico, visam criar, em um tempo mais dilatado, um imaginário de preferência a certos políticos.

Na Marcha para Jesus de 2013, após várias performances de artistas evangélicos, o pastor Silas assume a frente do evento convidando o público para uma oração responsiva em favor da nação brasileira. No mesmo palco, encontram-se juntos aqueles que seriam os candidatos em 2014, Pastor Everaldo e Eduardo Cunha. No discurso do pastor Silas, não há qualquer apelo a votos ou indicações, principalmente, por ainda não ser período eleitoral. No entanto, a presença dos futuros candidatos no palco e uma oração direcionada ao âmbito político remete uma futura campanha eleitoral destes personagens. Sob muitos aplausos do público, o discurso inicia da seguinte forma:

Estende a mão aqui, meu filho. Essa oração faz o inferno tremer gente. Repita comigo: Senhor Jesus, nós somos a igreja, e a tua palavra diz, se o que ligarmos na terra será ligado no céu. E nós ligamos, com a tua bênção sobre todas as autoridades, sejam evangélicos ou não evangélicos, presidente da república, governadores, prefeitos, deputados, vereadores, o executivo, o judiciário, o legislativo. Abençoamos as autoridades aqui representadas. E declaramos um Brasil de paz e de prosperidade. Jesus Cristo é o senhor do Brasil, amém ${ }^{17}$.

Certamente não há maior medo simbólico para um cristão do que o próprio inferno, sendo este o local de ausência de Deus (BOLLINI, 2007) que faz, plasticamente, um contraponto extremado ao céu, pois, se por um lado o inferno é a frustração e a condenação eterna, por outro lado, o céu é o pleno desabrochar do ser humano (SOARES, 2006). Ao iniciar

16 Disponível em: https://www.youtube.com/channel/UCtAXZSfs365AME4j1-YlJqw. Acesso em: 10 jun. 2017.

17 Disponível em: https://www.youtube.com/watch?v=i9AlAURJbks. Acesso em: 9 jun. 2017. 
uma oração afirmando que ela pode fazer o inferno tremer, o pastor transmite ao público a sensação de que esta oração tem a capacidade de afastar o inferno e, consequentemente, tranquilizar os fiéis que colocam suas esperanças no céu e nos futuros políticos no país. É um jogo entre a dualidade de céu e inferno ou medo e esperança.

Em 2015, após a eleição de Eduardo Cunha como presidente da Câmara, Silas Malafaia o parabenizou em sua conta do Twitter, que conta com mais de 1 milhão de seguidores ${ }^{18}$.

Figura 5 - Twitter Silas Malafaia Oficial

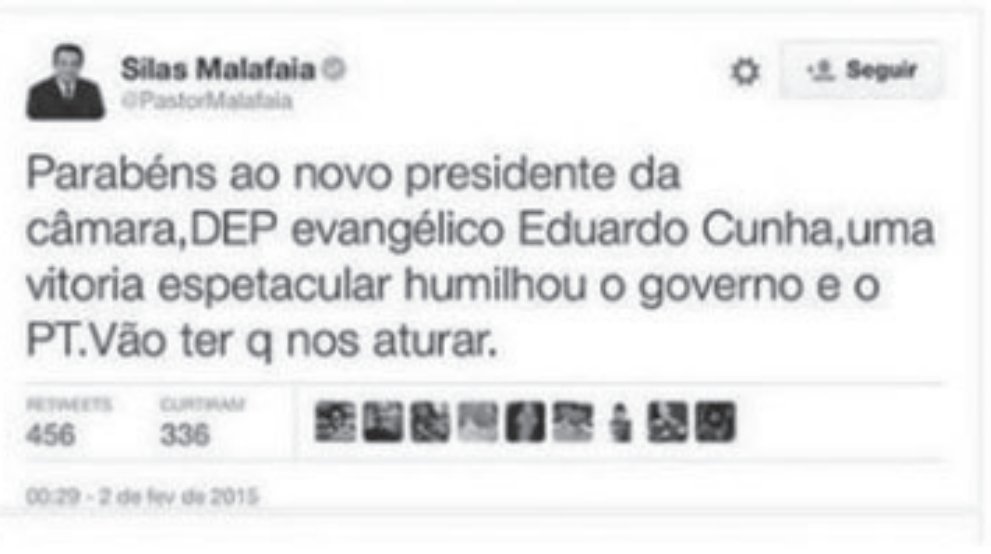

Fonte: https://twitter.com/PastorMalafaia. Acesso em: 6 jul. 2017.

A aproximação entre o pastor e Eduardo Cunha permanece até os anos seguintes. Na Marcha para Jesus de 2016, temos novamente a presença de Silas Malafaia, Pastor Everaldo e Eduardo Cunha. Silas apresenta o deputado eleito destacando sua importância na hierarquia política: "Pela primeira vez na história de nosso país, na história republicana, a terceira maior autoridade do país, o presidente da Câmara dos Deputados é um irmão nosso. Eu vou pedir para dar uma saudação o deputado Eduardo Cunha”. ${ }^{19}$

O deputado faz um breve discurso, o qual não conseguimos recuperar em sua íntegra, mas destacamos as frases utilizadas por ele: “Deus me colocou lá” e “o nosso povo merece respeito" ${ }^{20}$. Nesse frame, percebemos um sentimento de esperança e confiança, assinalamos, aliás que a palavra inferno não foi citada.

O deputado Eduardo Cunha foi preso no ano de 2017 e acusado de três crimes na operação Lava a Jato ${ }^{21}$. Após esse episódio, Silas tentou se desvincular da imagem de Eduardo Cunha por meio de vários vídeos em seu canal.

18 Número de seguidores extraído em 10 jun. 2017. Total real: 1.330 .910 usuários.

19 Disponível em: https://www.youtube.com/watch?v=KQSWyIjeUGY. Acesso em: 10 jun. 2017.

20 Disponível em: https://www.youtube.com/watch?v=KQSWyIjeUGY. Acesso em: 10 jun. 2017.

21 Disponível em: http://g1.globo.com/pr/parana/noticia/eduardo-cunha-e-condenador-a-15-anos-de-reclusao-por-tres-crimes-nalava-jato.ghtml. Acesso em: 10 jun. 2017. 


\section{Marco Feliciano em campanha}

São diversos discursos promovidos por Feliciano nas redes sociais no período eleitoral. No entanto, destacamos alguns pontos de sua campanha que julgamos serem mais apropriados ao escopo do nosso trabalho. Primeiramente, apresentamos o discurso do pastor Marco Feliciano em seu canal oficial do YouTube, quando busca o apoio de fiéis na divulgação de sua candidatura:

Você me conhece das minhas lutas, das minhas batalhas, não apenas como parlamentar, mas como pastor também. Sempre a perseguição parece ter sido o combustível que me põe de pé e me faz caminhar. Todavia, hoje eu tô aqui pra fazer um pedido de coração, porque eu estou numa luta, eu preciso do apoio, não apenas da família evangélica cristã, mas todas as famílias que prezam a família como ela é, no estado de São Paulo [...] Eu preciso do seu voto e estou aqui humildemente para pedir isso a você e a sua família. Mais ainda, como eu sou um deputado que lutei muito contra as pessoas que queriam destruir a família na sua base, ou seja, o governo que aí está, eu fui marcado pelo governo. O governo quando marca uma pessoa para o mau, eles tentam destruir a imagem da pessoa pra ela não ser reeleita nunca mais [...] Eu tenho uma conta eleitoral, eu não tenho um centavo nesta conta, porque nenhuma empresa quer apostar em mim como deputado federal, porque tem medo do nome da empresa, do nome dela ser unido ao meu nome Feliciano e depois sofrer retaliação, tanto do governo quanto de ativistas. [...] o Brasil precisa conhecer, que no estado de São Paulo, há muitas famílias conservadoras que não querem ver o fim da família tradicional [sic.] ${ }^{22}$.

O discurso inicia com o processo de vitimização e com a insinuação do fim da família tradicional. No imaginário coletivo evangélico, a frase "lutei muito contra as pessoas que queriam destruir a família na sua base” pode ter uma carga muito negativa e gerar um sentimento de perseguição aos que são favoráveis ao núcleo familiar tradicional. Nitidamente, o discurso desqualifica o governo federal de forma simbólica, pois não utiliza dados concretos da realidade político-econômica do país, mas utiliza frases simbólicas como: “fui marcado pelo governo”, “o governo quando marca uma pessoa para o mal”, “tenta destruir a imagem da pessoa”.

Nesse sentido, o deputado coloca sua esperança no voluntariado dos fiéis, pois, segundo o candidato, não havia dinheiro para pagar sua campanha. Para verificar tal dado, que pode ser considerado como a única informação concreta do discurso, acessamos ao site do Tribunal Superior Eleitoral (TSE) e constatamos que o deputado recebeu o valor de R\$

22 Disponível em: https://www.youtube.com/watch?v=L6pMi7UrqJ8. Acesso em: 8 jun. 2017. 
144.222,35³ para sua campanha, valor composto por doações de empresas, pessoas físicas e pelo Comitê Financeiro Único do PSC-SP, sendo que alguns depósitos foram realizados antes da divulgação deste vídeo.

Também recuperamos, por meio do site Eleições Uol, um panfleto, ou um "profetinha" como foi chamado por Feliciano, distribuído por meio dos Correios como carta pessoal. Trata-se de uma carta de Feliciano destinada ao seu possível eleitor. Nele, sua imagem é vinculada aos candidatos Geraldo Alckmin (PSDB), do governo de São Paulo, ao senador José Serra (PSDB) e ao deputado estadual Gilson Gomes (REDE).

Figura 6 - Material de Campanha distribuído pelos Correios

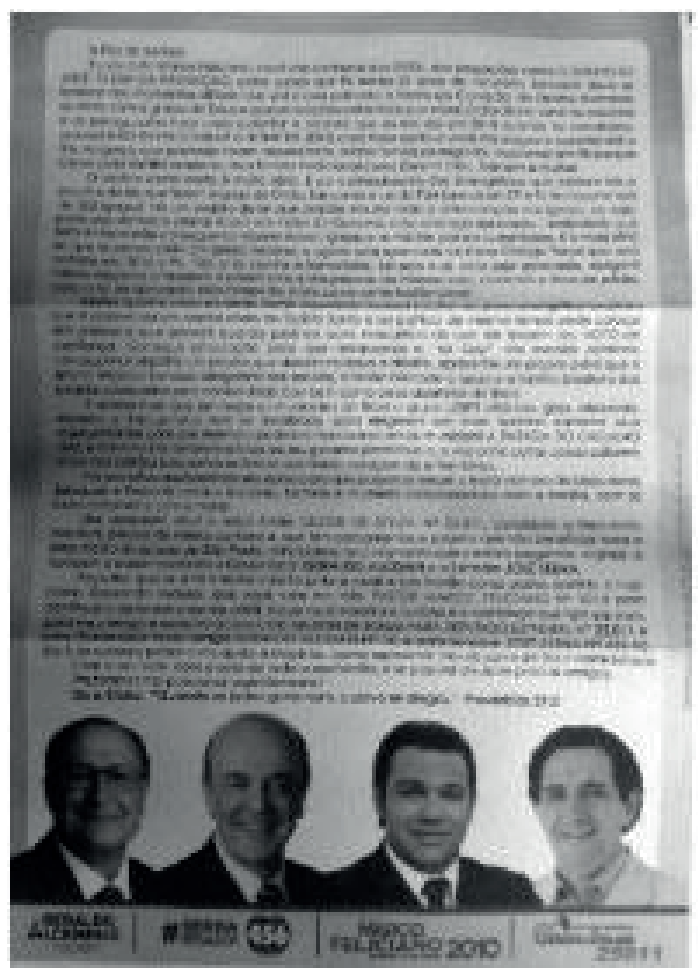

Fonte: Uol Eleições ${ }^{24}$.

O conteúdo, com caráter de seriedade, alerta o fiel dos perigos que a igreja pode enfrentar se caso nada for feito para alterar a realidade política do país. Como nos outros exemplos já citados, essa carta também mobiliza um processo de vitimização: “As igrejas que pastoreio foram depredadas, minha família perseguida, mas rompi em fé porque lutava

23 Dados disponíveis no site do TSE: http://inter01.tse.jus.br/spceweb.consulta.receitasdespesas2014/abrirTelaReceitasCandidato. action. Acesso em: 10 jun. 2017. $\mathrm{N}^{\circ}$ controle: 020100600000SP0012045, data de entrega: 19 nov. 2014.

24 Disponível em: https://eleicoes.uol.com.br/2014/noticias/2014/10/04/feliciano-usa-foto-de-serra-e-alckmin-em-panfleto-de-teorhomofobico.html. Acesso em: 10 jun. 2017. 
pela família”. Sobre o fato das igrejas depredadas, não encontramos qualquer informação que valide essa constatação, mesmo após diversas pesquisas em redes sociais, por meio dos aplicativos Netlytic, pesquisas no Google e YouTube.

Na carta, há ainda a citação da lei $P \operatorname{siu}{ }^{25}$ nas cidades de São Paulo e Rio de Janeiro, que, segundo Feliciano, já fechou mais de 300 igrejas evangélicas nestes municípios. E faz um apelo ao eleitor para que vote em Feliciano para que outros projetos, que visam acabar com a igreja e família, não sejam aprovados. Dentre estes projetos, Feliciano cita o PL 122, que criminaliza a homofobia. Nas palavras do pastor: "a mais séria lei que passou pelo congresso, a PL 122, a lei contra homofobia. Lei esta que, caso aprovada, obrigará líderes religiosos a fazerem o casamento entre pessoas do mesmo sexo, correndo risco de prisão”. Embora a lei não tenha nenhuma relação com a obrigação do casamento religioso de pessoas do mesmo sexo, a ênfase em "correndo o risco de prisão" e "As igrejas que pastoreio foram depredadas” podem promover um sentimento de medo e perseguição aos evangélicos do país.

As assessorias de imprensa de Geraldo Alckmin e Marco Feliciano foram questionadas pela reportagem do Uol. A assessoria de Alckmin afirmou que desconhece o material e a assessoria de Marco Feliciano afirmou que se trata de uma carta pessoal assinada por Marco Feliciano, na qual foram inseridas fotos de Alckmin e Serra apenas por serem da mesma coligação.

Pela análise desses materiais constatamos que a campanha de Marco Feliciano foi baseada em um jogo simbólico amparado por um discurso teológico que promove o medo, sem qualquer explicação concreta do cenário sobre a política brasileira ou projetos de políticas públicas.

\section{Resultados eleitorais dos candidatos evangélicos}

A despeito de termos como subsídios empíricos os discursos salvacionistas e messiânicos de dois pastores midiáticos, Silas Malafaia e Marco Feliciano, trazemos uma análise da capacidade de influência que a instrumentalização desse discurso pode ter na esfera política.

Assim, das principais lideranças a eles articulados, destacamos o Pastor Everaldo que conquistou 780.299 votos, sendo que a concentração dos votos está nos estados de São Paulo com (142.793) e do Rio de Janeiro com (136.143), ambos estados com grande presença evangélica. Foi o $5^{\circ}$ mais votado entre os 11 candidatos à presidência da República. Atualmente, sua atuação no debate eleitoral, promovido pela rede Globo de Televisão, está sendo questionada porque, após delações da Odebrecht, em 2017, foi revelado que Everaldo recebeu valores não declarados para sua campanha, além de recomendações, por

25 Lei que prevê multa ou o fechamento do estabelecimento que ultrapassar um limite de decibéis após um horário previamente determinado dentro do período noturno. A lei se aplica a todos estabelecimentos que fazem o uso de som. 
parte da Odebrecht, para ajudar Aécio Neves no debate. O caso na justiça segue em aberto até o momento ${ }^{26}$.

Outra liderança, Eduardo Cunha foi eleito com 232.708 votos, sendo que os municípios em que recebeu mais votos foram: Rio de Janeiro com 60.380, Belford Roxo com 23.776 e Itaboraí com 19.054 votos. Para verificar a relação religião e voto, novamente utilizamos os dados do IBGE (2010). A partir disso, constatamos que, em Belford Roxo, a população evangélica ultrapassa a população católica, pois, em 2010, eram 174.250 evangélicos e 152.503 católicos. O mesmo acontece com a cidade de Itaboraí, que conta com 85.147 evangélicos e 72.914 católicos, dados de 2010. A cidade do Rio de Janeiro, local onde Cunha foi mais votado, concentra o maior número de evangélicos do Estado (1.477.021) ${ }^{27}$, mas isso não faz com que os evangélicos sejam maioria no município, como acontece nos municípios de Belford Roxo e Itaboraí. A cidade do Rio de Janeiro possui maioria católica, com 3.229.192 pessoas residentes.

Marco Feliciano foi eleito com 398.087 votos, sendo o terceiro candidato mais votado no Estado de São Paulo. De acordo com nossa pesquisa, por meio dos dados do TSE, destacamos as zonas eleitorais que tiveram acima de três mil votos. Foram elas: São Mateus/ São Paulo (3.619), Franco da Rocha (3.392), Itaim Paulista/São Paulo (3.401), Orlândia (3.359), Brasilândia/São Paulo (3.277), Parelheiros/São Paulo (3.114) e São Sebastião (3.045). Cruzando esses dados com o censo IBGE (2010), percebemos, em algumas cidades, uma relação entre a presença de evangélicos das Assembleias de Deus com a quantidade de votos para Feliciano. São Paulo é a cidade com maior número de assembleianos, com 533.362 residentes. Se somadas as zonas eleitorais do município de São Paulo, Feliciano obteve ao todo 90.982 votos, o que equivale a $22 \%$ do total de votos conquistados.

Na cidade de Orlândia, que pontua com 3.359 votos, está localizada a igreja Catedral do Avivamento, igreja presidida por Marco Feliciano e que também faz parte da associação das igrejas Assembleias de Deus. As cidades de Franco da Rocha e São Sebastião também se destacaram no número de votos. Embora essas cidades não possuam expressividade numérica do número de fiéis evangélicos, outros fatores como alianças locais ou coesão de voto em igrejas podem ter colaborado com o destaque do pastor.

\section{Apontamentos finais}

Há muros que separam nações, há muros que dividem pobres e ricos, mas não há hoje no mundo um muro que separe os que têm medo dos que não têm medo ${ }^{28}$.

26 Disponível em: http:/g1.globo.com/jornal-nacional/noticia/2017/04/odebrecht-pediu-pastor-everaldo-para-ajudar-aecio-emdebate-de-201.html. Acesso em: 11 jun. 2017.

27 Dos 1.477.021 evangélicos residentes no município de Rio de Janeiro, 432.138 são assembleianos.

28 Discurso de Mia Couto, conferências do Estoril 2011. Disponível em: https://www.youtube.com/watch?v=jACccaTogxE. Acesso em: 15 nov. 2016. 
O discurso do medo foi, ao longo da história, utilizado como uma estratégia para grupos políticos tomarem ou manterem-se no poder. No Brasil, as relações entre lideranças religiosas, mídia e política estão cada vez mais imbricadas e, no período correspondente às campanhas eleitorais, aparecem como um exemplo e um importante objeto de estudo, permitindo visualizar, entre os evangélicos, um discurso de ódio e a utilização de inúmeros padrões de manipulação da cultura do medo.

Contudo, percebemos que o engajamento religioso na esfera política não se restringe ao período eleitoral, mas se coloca em uma situação de disputa política constante, seja para pressionar o sistema político a se comprometer com certos valores por eles defendidos, seja em uma análise mais ampla pela criação de um imaginário coletivo que se antagoniza as possibilidades de pluralização da democracia, resultando um conservadorismo em latência como parte de um projeto que se pretende hegemônico ${ }^{29}$.

A pluralidade e a diversidade contidas nos discursos progressistas acabam por pressionar os próprios discursos conservadores, já que eles são diametralmente opostos, constituindo uma relação dialética entre si (BOBBIO, 1994). Nesse sentido, a propagação de discursos de ódio nas redes sociais digitais, tidas como fonte de sistemas de representação da realidade, torna-se mais um elemento para os evangélicos, como estruturador do campo simbólico, podendo potencializar visões de mundo cada vez mais distantes da realidade e aparecendo como mais um elemento que expõe a fragilidade da estrutura democrática da política brasileira.

Não à toa, os principais propagadores desses discursos de ódio se ancoram em princípios salvacionistas, operando um entrecruzamento entre a fé tradicional e o messianismo político (GIRARDET, 1987) na pessoa do profeta (PREUSS, 2015) carismático e demagógico, capaz de oferecer caminhos, pois é o messias político que pode restaurar a autonomia perdida e concluir a esperança de um povo (WEBER, 1991; PEREIRA DE QUEIRÓZ, 1976).

Os messias (profetas) políticos referidos em nossa pesquisa operam um discurso maniqueísta nas duplicidades céu e inferno, bem e mal, esperança e medo, que não se colocam de forma metafísica, mas que se concretizam na denominação de um inimigo em comum - como os destruidores da família, por exemplo - e em sua demonização até a perda da humanidade como um elemento capaz de gerar empatia.

O conservadorismo como ação e valor político usa, potencialmente, a produção do discurso do medo como uma estratégia de poder a fim de obter a obediência e o controle de seus fiéis pelos elementos simbólicos contidos no axioma orwelliano "guerra é paz", em que discursos violentos são instrumentalizados por um lado, mas também a afeição que um pastor-messias-profeta suscita em seus seguidores por outro. O que pode resultar em uma

29 Essa hipótese explicativa, de um conservadorismo em latência, no sentido de inserido em uma determinada temporalidade que se põe em desenvolvimento quer em oposição à ideários e práticas emancipatórias calcadas na pluralidade e na diversidade, e afinado à valores capitalistas tais como o empreendedorismo e a inserção no consumo material, foi apresentada na $7^{a}$ Compolítica: http://www. compolitica.org/home/wp-content/uploads/2017/06/Chicarino_Ortunes_Martinho_Evang\%C3\%A9licos-e-a-Pol\%C3\%ADtica_Umnovo-conservadorismo-em-lat\%C3\%AAncia.pdf. 
espetacularização da política e da religião, no que Debord (1997) chamou de comportamento hipnótico, quando a realidade é materialmente invadida pela contemplação do espetáculo.

\section{Referências}

AZEVEDO, F. Agendamento da política. In: ALBINO, A.; CANELAS, R. (Org.). Comunicação e Política. Conceitos e abordagens. Salvador: Editora Unesp, 2004.

BERGER, P. L. Una Gloria Remota: avere fede nell'epoca del pluralismo. Bologna: II Mulino, 1994. BOBBIO, N. As ideologias e o poder em crise. $3^{\circ}$ edição. Brasília: Universidade de Brasília. 1994

BOLLINI, C. Cidadãos do Céu. Ciberteologia Revista de Teologia \& Cultura, n. 11, maio/jun., 2007.

BOURDIEU, P. Sobre a televisão. Rio de Janeiro: Jorge Zahar, 1997.

BURITY, J. A. Religião e Política na Fronteira: desinstitucionalização e deslocamento numa relação historicamente polêmica. Revista de Estudos da Religião - REVER, São Paulo, n. 4, ano 01, 2001.

CASANOVA, J. Public Religion in The Modern World. Chicago: The Chicago University Press, 1994.

CHAIA, V.; BRUGNAGO, F. A nova polarização política nas eleições de 2014: Radicalização ideológica da direita no mundo contemporâneo do Facebook. Revista Aurora, São Paulo, v. 7, n. 21. 2014.

CROATTO, S. As linguagens da experiência religiosa. São Paulo: Paulinas, 2010.

CUnHA, M. N. Do Púlpito às Mídias sociais: Evangélicos na Política e Ativismo Digital. Curitiba: Editora Prismas, 2017.

DANTAS, B. S. A. Religião e Política: Ideologia e ação da "Bancada Evangélica” na Câmara Federal. Tese de doutoramento em Psicologia Social. São Paulo: PUC-SP, 2011.

DEBORD, G. A sociedade do espetáculo. Rio de Janeiro: Contraponto. 1997.

GIRARDET, R. Mitos e Mitologias Políticas. São Paulo: Companhia das Letras. 1987.

GLASSNER, B. Cultura do Medo: por que tememos cada vez mais o que deveríamos temer cada vez menos. São Paulo: Editora Francis. 2003.

HABERMAS, J. Religion in the Public Sphere. European Journal of Philosophy, v. 14, p. 1-25, 2006.

HOBBES, T. Leviatã. Os Pensadores. São Paulo: Abril Cultural. 1979.

JENKINS, H. Cultura da Convergência. São Paulo: Aleph, 2008.

KEHL, M. R. Elogio do medo. In: NOVAES, A. Ensaios sobre o Medo. São Paulo: Editora Senac, p. 135152, 2007.

LIMONGI, M. I. A racionalização do medo na política. In: NOVAES, A. Ensaios sobre o Medo. São Paulo: Editora Senac. 2007.

MACHADO, M. D. C. Política e Religião: Participação dos evangélicos nas eleições. Rio de Janeiro: Editora FGV, 2006.

MALINI, F.; ANTOUN, H. A internet e a rua. Ciberativismo e mobilização nas redes sociais. Porto Alegre: Editora Sulina, 2013.

MAQUIAVEL, N. O Príncipe. Rio de Janeiro: Editora Civilização Brasileira. 1969.

MARANHÃO, E. M. A. “É prá baixar o porrete!” notas iniciais sobre discursos punitivos/discriminatórios acerca das homossexualidades e transgeneridades. Mandrágora, v. 21, n. 21, p. 47-84. 2015.

144 Intercom - RBCC

São Paulo, v. 42, n. 2, p.121-146, maio/ago. 2019 
MARTINO. L. M. S. Mídia, Religião e Sociedade: Das palavras às redes digitais. São Paulo: Paulus, 2016. NASCIMENTO, A. F. N. "Eu amo homossexuais como eu amo bandidos": o pensamento religioso de Silas Malafaia. In: MARANHÃO FILHO, E. M. A. (Org.). Anais do 10 Simpósio Sudeste da ABHR, $1^{\circ}$ Simpósio Internacional da ABHR, Diversidades e (In)Tolerâncias Religiosas. São Paulo: ABHR, p. 1730-1740, 2013. ORO, I. P. O Outro é o Demônio: uma análise sociológica do fundamentalismo. São Paulo: Paulus. 1996. PEREIRA DE QUEIRÓZ, M. I. O messianismo no Brasil e no mundo. São Paulo: Alfa-Ômega. 1976. PIERUCCI, A. F.; MARIANO, R. O envolvimento dos pentecostais na eleição de Collor. Novos Estudos Cebrap, n. 34, p. 92-106, nov. 1992

PREUSS, L. P. As telerreligiões no telespaço público: O programa Vitória em Cristo e a estratégia de mesclar evangelização e pregação política. Dissertação de mestrado defendida na Escola de Comunicação e Artes ECA-USP. São Paulo. 2015.

SAMPAIO, T. A mídia e a campanha permanente: a disputa pela atribuição de responsabilidade no primeiro mandato da presidente Dilma Rousseff (2011-2014). In: $10^{\circ}$ ENCONTRO ABCP, 2016. Anais....

SOARES, A. M. L. Morte e inferno: um ponto de vista cristão. Ciberteologia Revista de Teologia \& Cultura, n. 4, 2006.

SOUZA, A.; LAMOUNIER, B. A feitura da nova constituição: um reexame da cultura política brasileira. In: LAMOUNIER, B. (Org.). De Geisel a Collor: o balanço da transição. Editora Sumaré, 1990.

WEBER, M. Economia e Sociedade. Brasília: UNB. 1991.

WEBER, M. A psicologia Social das Religiões Mundiais. In: Ensaios de Sociologia. Rio de Janeiro: LTC. 2010.

YIN, R. K. Estudo de caso. Planejamento e métodos. São Paulo: Bookman, 2009.

ZABATIERO, J. P. T. Hermenêutica fundamentalista: uma estética do interpretar. Estudos de Religião. São Bernardo do Campo, v. 22, n. 35, 2008, p. 14-27.

\section{Leandro Ortunes}

Doutorando e mestre em Ciências Sociais pela PUC-SP, com Estágio Doutoral (CAPES-PDSE) na Universidad de Valladolid, Espanha. Especialista em Ciências da Religião pela PUC-SP. Especialista em Relações Internacionais pela FAAP. Desenvolve pesquisas nas áreas de Mídia, Política e Religião. Atualmente é membro do NEAMP - Núcleo de Estudos em Arte, Mídia e Política - PUC-SP e do Grupo de Estudos de Mídia e Religião (MIRE) da INTERCOM. E-mail: leandroortunes@uol.com.br.

\section{Silvana Gobbi Martinho}

Doutoranda em Ciências Sociais na área de Ciência Política pela Pontifícia Universidade Católica de São Paulo (PUC-SP). Bolsista CAPES e Mestre em Ciências Sociais na área de Ciência Política pela Pontifícia Universidade Católica de São Paulo (PUC-SP). Graduada em Ciências Sociais pela Pontifícia Universidade Católica de São Paulo (PUC-SP). Professora de Ciência Política no curso de Direito da Universidade Nove de Julho (UNINOVE - 2012-2016) Pesquisadora do Núcleo de Estudos 
em Arte, Mídia e Política (NEAMP) da PUC-SP. Editora da Revista Aurora da PUC-SP (2007-2012). Atua principalmente nos temas: comunicação política, cultura política, discurso político, política brasileira, democracia, liderança política e ciberpolítica. Possui um artigo publicado em revista científica e quatro capítulos de livros. E-mail: silgmartinho@gmail.com.

\section{Tathiana Senne Chicarino}

Doutoranda e Mestre em Ciências Sociais na área de Ciência Política pela Pontifícia Universidade Católica de São Paulo (PUC-SP). Bolsista FAPESP. Graduada em Sociologia e Política pela Fundação Escola de Sociologia e Política de São Paulo (2010). Professora de pós-graduação na Fundação Escola de Sociologia e Política de São Paulo. Pesquisadora do Núcleo de Estudos em Arte, Mídia e Política (NEAMP) da PUC-SP e do Grupo de Pesquisa "Comunicação e Sociedade do Espetáculo” da Casper Líbero. Editora Assistente da Revista Aurora da PUC-SP. Colunista especial do site da revista Carta Capital. Atua principalmente nos temas: comunicação política, cultura política, discurso político, política brasileira, democracia, liderança política e ciberpolítica. Possui nove artigos publicados em revistas científicas, sete livros organizados e/ou publicados, oito capítulos de livros e participa assiduamente dos principais congressos nacionais e internacionais da área. E-mail: tschicarino@gmail.com.

Recebido em: 09.02.2018

Aprovado em: 22.05.2019

Este artigo é publicado em acesso aberto (Open Access) sob a licença Creative Commons Attribution Non-Commercial (CC-BY-NC), que permite uso, distribuição e reprodução em qualquer meio, sem restrições, desde que sem fins comerciais e que o trabalho original seja corretamente citado. 